\title{
Anatomy in the Third Reich: An Outline, Part 2. Bodies for Anatomy and Related Medical Disciplines
}

\author{
S. HILDEBRANDT* \\ Division of Anatomical Sciences, Office of Medical Education, \\ University of Michigan Medical School, Ann Arbor, Michigan
}

\begin{abstract}
All anatomical departments of German universities used bodies of the executed and other victims of the National Socialist (NS) regime for their work. Many of these victims had been executed in prisons and were members of the German political opposition; others had perished in camps for prisoners of war or forced laborers and concentration camps, and were of various European and other descent. Anatomists generally welcomed the increased influx of "fresh material" for purposes of research and education of the growing numbers of medical students. No anatomist is known to have refused work with the bodies of NS victims. Other medical disciplines also made use of these bodies, among them were racial hygienists and neuropathologists. In the late 19th and early 20th century, the fields of anatomy, physical anthropology, and racial hygiene (eugenics) were closely related in their subject matter. Anatomists were involved in the biological foundation of racial hygiene, most prominently among them Eugen Fischer. The discipline was established as part of the medical curriculum after 1920. Racial hygiene became the scientific justification for NS policies that led to racial discrimination, involuntary sterilization and ultimately mass murder. Anatomists taught racial hygiene throughout the Third Reich and did research in this area. Some were actively involved in NS policies through propaganda and evaluations for the so-called Genetic Health Courts, whereas others became victims of their own science in that they were dismissed for racial reasons. Clin. Anat. 22:894-905, 2009. @ 2009 Wiley-Liss, Inc.
\end{abstract}

Key words: anatomy; National Socialism; racial hygiene; eugenics; bodies of the executed

\section{INTRODUCTION}

Part 1 of "Anatomy in the Third Reich" has focused on the relationship between National Socialist (NS) politics, anatomical institutions, and anatomists. The German government was traditionally responsible for the body supply for anatomical dissection including the bodies of the executed. A unique connection existed between the NS government and the anatomical departments in that this regime used executions in a heretofore unknown frequency, especially during the war years. Part 2 will examine this interaction more closely by investigating how widespread the use of bodies of NS victims was in anatomy and related medical disciplines and who these victims were. In addition, the as yet never explored relationship between anatomy and racial hygiene is considered. It will become apparent that individual anatomists in their role as racial hygienists were involved in the victimization of a large part of the population of Germany and its occupied territories.

\footnotetext{
*Correspondence to: Dr. Sabine Hildebrandt, Division of Anatomical Sciences, Office of Medical Education, University of Michigan Medical School, 3767 Medical Science Building II, Catherine Street, Ann Arbor, MI 48109-0608, USA.

E-mail: shilde@umich. edu

Received 22 April 2009; Revised 2 September 2009; Accepted 13 September 2009
}

Published online 16 October 2009 in Wiley InterScience (www. interscience.wiley.com). DOI 10.1002/ca.20873 


\section{METHODS}

Literature was collected and analyzed on the subjects of body procurement in anatomy and related medical disciplines in the early 20th century and the Third Reich, on the identity of the persons whose bodies were used in anatomy, and on the relationship between racial hygiene and anatomy. Specifically, detailed reports on the NS history of individual anatomical departments and their interaction with the NS judicial system were examined. Many of these studies, e.g., Noack (2007), Waltenbacher (2008, personal communication, December 16, 2008), and Winkelmann and Schagen (2009), have only recently become feasible due to the reunification of Germany and the opening of formerly inaccessible archives. All of these authors made original archival material available for this article. In addition, original publications by German anatomists published between 1940 and 1945 were examined in terms of the sources of material.

\section{Bodies Used in Anatomical Departments in NS Germany}

Table 1 summarizes the available information on the body supply of the 31 anatomical departments at German universities from 1933 to 1945 (see Part 1). It includes data on the existence of body registers from this time, the different categories for sources of the bodies, the total number of bodies received by the departments in the time period, and the number and possible identity of the bodies of the executed. Detailed studies of still existing or reconstructed body registers are available for 10 anatomical departments, whereas for all other universities, except Dorpat, at least some information exists concerning the body supply.

The traditional sources before 1933 in Germany and other countries were unclaimed bodies from prisons and general and psychiatric hospitals, as well as bodies of the executed. Most countries around the world practiced capital punishment and performed executions. At the same time, body donations were extremely rare, as donation programs were established only in the second half of the 20th century (Hildebrandt, 2008). Bodies of the executed were infrequent in Germany before 1933 due to low execution rates. Between 1907 and 1932 there were a total of 393 to 478 civilians executed in Germany (an average of 16-19 per year). However, during the NS period from 1933 to 1945 there were about 12,000 to 15,000 civilian plus another minimum of 15,000 military executions performed (an average of 1,000 to 1,250 civilians and 1,250 military per year), most of them in the war years (numbers differ from source to source, reviewed in Forsbach, 2006; p 529, and Hildebrandt, 2008). So, while unclaimed bodies (" $U$ " in Table 1) continued to be available to the anatomical departments during the NS period, there was a nearly 100 -fold increased influx of bodies of the executed from the official execution chambers, especially from 1941 on. This increase was mostly due to the widening of the definition of "high treason" and desertion from the military. In addition, the war brought new sources of bodies from camps housing forced laborers from other European countries ("forced labor camps," "F"), concentration camps (KZ), camps for prisoners of war (POW), and bodies of persons executed directly by the Gestapo (Geheime Staatspolizei, secret state police, "G") through Sonderbehandlung (special extermination actions, Forsbach, 2006; p 537ff).

Table 1 shows that all German anatomical departments without exception received bodies of the executed from execution chambers. Other documented ("F," "POW," "G") or highly likely provenances of bodies ("F?," "POW?," "G?") were camps for forced laborers (12 anatomical departments) and prisoners of war (10) in the vicinity of an anatomical department, and bodies of persons killed by the Gestapo (11). Bodies from concentration camps were delivered to eight anatomical departments. These were mostly not the large extermination camps like Auschwitz, but smaller facilities with a lower percentage of Jewish prisoners and a larger percentage of politically oppositionally active persons and their families and other prisoners. The total number of bodies per institute used for dissection and research during the NS period, where data are available, ranged from 336 in Strassburg to 5,341 adults in Vienna. The percentage of the bodies of the executed ranged from $9 \%$ in Jena to $45 \%$ in Göttingen, total numbers ranging from 53 in Giessen to a documented 1,377 in Vienna, and a potential 4,600 in Berlin (not all of them were used for dissection, Winkelmann and Schagen, 2009; p 165). Efforts have been made to identify the victims of executions who were dissected in anatomical departments. So far, extensive data are available for Bonn, Jena, Strassburg, and Vienna, whereas some names have been identified in Berlin, Freiburg, Giessen, Hamburg, Heidelberg, Königsberg, Marburg, and Tübingen.

\section{The Victims}

Most of the victims of capital punishment and from camps were of German, Austrian, Polish, Russian, and other European decent, but non-Europeans including US-citizens are also documented. Only a minority of the bodies were those of European Jews and other so-called "non-Aryan" minorities, such as Roma and Sinti, as by 1941 most of them had either left Germany or had been transported to extermination camps (Druml, 1999). Exceptions were the victims of Hirt's project in Strassburg, who were all Jewish. These individuals have been identified recently, even though Hirt had tried to obscure their identities by having the concentration camp tattoos with their identification numbers removed (Lang, 2007). The identification of the bodies of the executed delivered to the anatomical institute in Vienna showed that of the 1,377 bodies only eight were of Jewish origin, and that no bodies had been received from the nearby concentration camp Mauthausen (Malina and Spann, 1999; Angetter, 2000). Similarly, the account of 191 bodies of the executed dissected in the anatomical department in Bonn showed 
TABLE 1. Body Supply of Anatomical Departments of German Universities 1933-1945

\begin{tabular}{|c|c|c|c|c|c|}
\hline City (source) & $\begin{array}{l}\text { Body-register } \\
\text { existent? }\end{array}$ & $\begin{array}{c}\text { Sources of } \\
\text { bodies }\end{array}$ & $\begin{array}{l}\text { Total number } \\
\text { of bodies }\end{array}$ & $\begin{array}{c}\text { Number of } \\
\text { executed (\%) }\end{array}$ & $\begin{array}{l}\text { Execution } \\
\text { victims } \\
\text { identified? }\end{array}$ \\
\hline Berlin (Noack, 2007) & No & $U, E$ & $?$ & $\begin{array}{l}\text { Potentially } \\
\text { over } 4,600\end{array}$ & Some \\
\hline $\begin{array}{l}\text { Bonn (Stöhr, 1943; } \\
\text { Forsbach, 2006) }\end{array}$ & Yes & $U, E, G, F, P O W$ & 1,025 & $191(19 \%)$ & Yes, all E \\
\hline $\begin{array}{l}\text { Breslau (Aly, 1994; } \\
\text { Waltenbacher, 2008, } \\
\text { personal } \\
\text { communication, } \\
\text { December 16, 2008) }\end{array}$ & $?$ & U, E (compare Posen) & $?$ & $?$ & $?$ \\
\hline Danzig (Neander, 2006) & No & $\mathrm{U}, \mathrm{E}, \mathrm{G}, \mathrm{F} ?, \mathrm{KZ}$ & $?$ & $?$ & $?$ \\
\hline Dorpat & $?$ & & ? & ? & ? \\
\hline $\begin{array}{l}\text { Erlangen (Hett, 1943; } \\
\quad \text { Wendehorst, 1993) }\end{array}$ & $?$ & U, E, F?, POW?, G? & $?$ & $?$ & $?$ \\
\hline $\begin{array}{l}\text { Frankfurt (Schreiber, } \\
\text { 1942; Schmid, 1965; } \\
\text { Stuchlik, 1984) }\end{array}$ & $?$ & $U, E$ & $?$ & $?$ & $?$ \\
\hline $\begin{array}{l}\text { Freiburg (Grün et al., } \\
\text { 2002; Seidler and } \\
\text { Leven, 2007) }\end{array}$ & No & $U, E, F, P O W$ & $?$ & $?$ & Some \\
\hline $\begin{array}{l}\text { Giessen (Bembenek and } \\
\text { Schumacher, 1980; } \\
\text { Jakobi et al., 1989; } \\
\text { Oehler-Klein, 2007) }\end{array}$ & Yes & $U, E, G, K Z, F ?$ & 405 & $53(13 \%)$ & Some \\
\hline $\begin{array}{l}\text { Göttingen (Beushausen } \\
\text { et al., 1998) }\end{array}$ & Yes? & $U, E, G, F$ & $\begin{array}{l}517 \text { (Numbers } \\
\text { for } 1937-44 \text { ) }\end{array}$ & $233(45 \%)$ & $?$ \\
\hline Graz (Klee, 2003) & $?$ & $U, G$ & ? & $?$ & ? \\
\hline $\begin{array}{l}\text { Greifswald (Fleischer, } \\
\text { 1940) }\end{array}$ & $?$ & $\mathrm{U}, \mathrm{E}$ & $?$ & $?$ & $?$ \\
\hline Halle (Viebig, 2002) & No & $\mathrm{U}, \mathrm{E}, \mathrm{F}, \mathrm{POW}$ & $?$ & ca. 108 & No \\
\hline $\begin{array}{l}\text { Hamburg (Roth, 1984; } \\
\text { Rothmaler, 1990) }\end{array}$ & Yes & $\mathrm{U}, \mathrm{E}, \mathrm{KZ}, \mathrm{G}$ & $?$ & $>315$ & Some \\
\hline $\begin{array}{l}\text { Heidelberg (Eckart et al., } \\
2006)\end{array}$ & Yes & $U, E, F, P O W$ & 970 & $280(29 \%)$ & Some \\
\hline $\begin{array}{c}\text { Innsbruck (Schneider, } \\
\text { 1944; Huter, 1970) }\end{array}$ & $?$ & $U, E$ & $?$ & $?$ & $?$ \\
\hline $\begin{array}{l}\text { Jena (Redies et al., } \\
\text { 2005) }\end{array}$ & Yes & $\mathrm{U}, \mathrm{E}, \mathrm{KZ}, \mathrm{F}, \mathrm{POW}$ ? & 2,224 & $200(9 \%)$ & Yes, most \\
\hline $\begin{array}{l}\text { Kiel (Zitzelsperger, } \\
1944)\end{array}$ & $?$ & $U, E$ & $?$ & $?$ & $?$ \\
\hline $\begin{array}{l}\text { Köln (Cologne) } \\
\quad \text { (Ortmann, 1986) }\end{array}$ & $?$ & $U, E$ & $?$ & $?$ & No \\
\hline $\begin{array}{l}\text { Königsberg (Bargmann, } \\
\text { 1942; Bargmann and } \\
\text { Scheffler, 1943; } \\
\text { Ziesche, 1943; Steege, } \\
\text { 1944; Aly, 1994; } \\
\text { Lawrynowicz, 1999) }\end{array}$ & $?$ & $U, E$ & $?$ & $?$ & Some \\
\hline $\begin{array}{l}\text { Leipzig (Ferner, 1940; } \\
\text { Voss, 1940) }\end{array}$ & $?$ & $U, E$ & $?$ & $?$ & $?$ \\
\hline $\begin{array}{l}\text { Marburg (Aumüller, } \\
\text { 1991; Aumüller et al., } \\
\text { 2001) }\end{array}$ & Yes & $\mathrm{U}, \mathrm{E}, \mathrm{F}, \mathrm{G}, \mathrm{POW}, \mathrm{KZ}$ & $\begin{array}{r}\text { Estimated } \\
800-900\end{array}$ & $?$ & Some \\
\hline $\begin{array}{l}\text { München (Munich) } \\
\text { (Bauer, 1940) }\end{array}$ & $?$ & $U, E$ & $?$ & $?$ & $?$ \\
\hline $\begin{array}{l}\text { Münster (Waltenbacher, } \\
\text { personal } \\
\text { communication, } \\
\text { December } 16,2008 \text { ) }\end{array}$ & $?$ & $U, E$ & $?$ & $?$ & $?$ \\
\hline Posen (Aly et al., 1994) & No & $U, E, K Z, G, P O W ?, F ?$ & ? & ? & ? \\
\hline $\begin{array}{l}\text { Prague (Waltenbacher, } \\
2008 \text { ) }\end{array}$ & $?$ & Probably U and E & $?$ & $?$ & $?$ \\
\hline $\begin{array}{l}\text { Rostock (Waltenbacher, } \\
\text { 2008) }\end{array}$ & Probably & $U, E$ & $?$ & $?$ & $?$ \\
\hline
\end{tabular}


TABLE 1. (Continued)

\begin{tabular}{|c|c|c|c|c|c|}
\hline City (source) & $\begin{array}{l}\text { Body-register } \\
\text { existent? }\end{array}$ & $\begin{array}{l}\text { Sources of } \\
\text { bodies }\end{array}$ & $\begin{array}{l}\text { Total number } \\
\text { of bodies }\end{array}$ & $\begin{array}{c}\text { Number of } \\
\text { executed (\%) }\end{array}$ & $\begin{array}{l}\text { Execution } \\
\text { victims } \\
\text { identified? }\end{array}$ \\
\hline $\begin{array}{l}\text { Strassburg (Steegmann, } \\
\text { 2005; Lang, 2007) }\end{array}$ & No & U?, E, KZ, POW & $\begin{array}{l}250-300+ \\
86=336-386\end{array}$ & $\begin{array}{c}\text { At least } \\
86(22-26 \%)\end{array}$ & All 86 \\
\hline $\begin{array}{l}\text { Tübingen (Mörike, 1988; } \\
\text { Drews, 1992; } \\
\text { Schönhagen, 1992) }\end{array}$ & Yes & $\begin{array}{c}\text { U, E, F' } \\
P O W, G, K Z ?\end{array}$ & 1,077 & $\begin{array}{l}\text { Estimated } \\
285(26 \%)\end{array}$ & Some \\
\hline $\begin{array}{l}\text { Wien (Vienna) (Malina } \\
\text { and Spann, 1999) }\end{array}$ & No & $U, E, G$ & $\begin{array}{c}>5,341+7,000 \\
\text { children } \\
\text { (incl. miscarriages } \\
\text { and stillbirths) } \\
\text { numbers for } \\
1938-45\end{array}$ & $>1,377(26 \%)$ & Yes \\
\hline $\begin{array}{l}\text { Würzburg (von Hayek, } \\
\text { 1940a,b; Münch, } \\
\text { 1978) }\end{array}$ & $?$ & $U, E$ & 1,003 & $?$ & $?$ \\
\hline
\end{tabular}

Sources of bodies: $U$, traditional "unclaimed bodies" from hospitals, prisons, psychiatric hospitals, suicides, and donations; F, forced Labor camp; KZ, Konzentrationslager (concentration camp); POW, prisoner of war camp; G, executed by Gestapo; $\mathrm{E}$, executed in execution chambers. A "?" behind the source denotes that the source is most likely, but some discrepancy exists in the references.

only one person whose religion was listed as Jewish (Forsbach, 2006). In Jena, the number of bodies of persons having died in prisons, frequently suicides, was much smaller than that of bodies of the executed. The nationalities of those prisoners were given as Polish and Jewish (without national identification) and the dissected included a Russian child (Redies et al., 2005). The latter may have been the child of a Russian woman forced into work in NS Germany, similar to a report from Freiburg. The anatomical institute in Freiburg had received the bodies of 10 Russian, 9 Polish, and 1 Romanian forced laborers, including those of 15 children born in 1943 and 1944 . The death rate of infants born to the millions of forced laborers from Eastern Europe was around 85\% (Schwarze, 1997; p 174/175; Speck, 2002; p 444/445; Zimmermann, 2007). These forced laborers were subject to especially harsh treatment in cases of so-called "racial defilement," i.e., a sexual relationship between a forced laborer and a German. The prisoner was executed and the German partner, generally a woman, could be sent to a concentration camp (Drews, 1992; Arbogast, 1998).

The increase in the number of civilian and military executions, especially during the war years, was closely associated with the NS regime's efforts to protect itself from its perceived enemies from within. Although these enemies were first seen in the ranks of the communist party, the focus shifted later to the social democrats and then to anybody who fell under the increasingly arbitrary definitions of high treason, including many apolitical but disillusioned citizens of the expanding Reich (Form and Schiller, 2005; p 779). Thus a great percentage of bodies used for dissection during the war years were those of political prisoners. The Volksgerichtshof (People's Court) in Berlin under President Roland Freisler was at the center of the prosecution of civilian high profile treason cases. After the war Hermann Stieve, chairman of the anatomical department at the University of
Berlin, had compiled a list with the names of 182 women whose bodies he had used for his research. Many of these women were German members of the Rote Kapelle (Red Orchestra) espionage ring, but they also included the American born Mildred von Harnack (Oleschinski, 1992; Brysac, 2000; p 394). Military courts generally convicted deserters of high treason and passed down verdicts of capital punishment. These victims were German, Austrian, and any other nationality drafted into service for the German military. One such deserter was Franz Dollnig, a 21-year-old Austrian conscientious objector, whose body was dissected at the University of Graz. He was executed on May 12, 1944, and his family paid 230 Reichsmark for an urn supposedly containing his ashes. However, his remains were found at the Graz anatomical institute in 1946 (Halbrainer, 2000).

\section{Reaction of Anatomists to "New Material" from Camps and Executions}

The complaint by anatomists of a lack of bodies for dissection and research had been a constant one throughout the history of anatomy (Hildebrandt, 2008). It is well-documented for Germany after 1933 in communications between anatomical departments and governmental agencies until the beginning of the war (e.g., Greifswald, Vienna, Erlangen, Halle, Heidelberg, Innsbruck: Bussche, 1989; p 156ff; Bonn: Forsbach, 2006). At the time, anatomists theorized that the lack of bodies, including those of the executed, might be due to the fact that relatives refused to give their consent to dissection in case the body should reveal signs of hereditary disease that might alert the "Erbgesundheitsgericht" (Genetic Health Court) and endanger the family. In addition, some psychiatric institutions delivered fewer bodies to the anatomical departments because their patients had been moved to central extermination facilities within the framework of the NS euthanasia program, and the bodies of the murdered 
patients vanished in those facilities, usually by incineration (Bussche, 1989; p 156ff; Beushausen et al., 1998; p 233ff; Noack, 2007; p 14/15). With the beginning of the war some anatomists became aware of a new source of "material" in the increasing availability of bodies from various camps and inquired into the possibility of having them shipped to their departments. Pernkopf suggested the use of bodies of Polish prisoners for Vienna, and Hirt requested those of Russian prisoners of war for Strassburg. Spanner called for the building of execution chambers in Danzig for a more convenient body supply for his department there. The anatomical department of the University of Hamburg applied successfully for the delivery of bodies from the nearby concentration camp Neuengamme (Bussche, 1989; p 156 ff; Hildebrandt, 2006). In 1944, Goerttler in Heidelberg and Nauck in Freiburg asked the authorities to provide the bodies of prisoners of war for their departments (Seidler and Leven, 2007; p 512/513). At the same time, the numbers of executions had so greatly increased in other cities that, anatomical departments ran out of storage space for the bodies and had to refuse them, e.g., in 1943 in Jena and Innsbruck (Bussche, 1989; p 156 ff).

The bodies of the executed were of special interest for the anatomists, as they were generally those of younger, healthy persons, the "material" was fresh and its arrival could be anticipated and thus work better planned (Hildebrandt, 2008). Bodies from concentration camps were considered less desirable by some anatomists, as they tended to be emaciated and potentially carried infectious agents. Indeed, Gustav von Hirschheydt, dissector at the anatomical institute of Posen, died from typhus after being bitten by a louse from the body of a Jewish prisoner. In collaboration with Hermann Voss, he had produced and sold plaster casts of the faces of dead Jews from a nearby concentration camp to the anthropological museum in Vienna. (Aly, 1994, 2003).

Not all bodies of the executed were released for dissection by their relatives. This led in some cities to the practice of anatomists harvesting fresh "material" secretly from the executed in the execution chambers, before the bodies were handed over to the family. Documents show that Johannes Hett, Rudolf Spanner, and Max Clara used these sources of "material" (Noack, 2007; p 12). Hett needed fresh specimens for his histological work and complained to the authorities about a lack of freshness of the bodies of the executed available to the department of anatomy in Erlangen. In response, he was sent a living Polish prisoner of war, who was to be executed in the basement of the institute. Hett protested against this plan indignantly, but accepted the body after the man was executed outside the institute (Wendehorst, 1993; p 237/238). Another complaint about "quality of material" was lodged by a Frankfurt anatomist. He stated in a letter to the authorities in 1940 that the executed had obviously been decapitated with a defective execution apparatus, thus leading to contusions in the neck area that made this region unsuitable for dissection, and asked, "in the interest of science, which alone we all should serve" if the apparatus could be repaired or replaced ([translation by author], Schmid, 1965; p 104/105).

\section{Impact on Medical Students}

Especially during the war years, all medical students studying anatomy were directly confronted with the policies of the NS regime through the bodies they were dissecting. Depending on their provenance from camps or directly from the execution chambers, these bodies frequently showed clear marks of physical abuse and starvation in the case of camp inmates and of the manner of execution in the often young and healthy executed. Hoimar von Ditfurth, a student of Stieve's in Berlin, remembered that many bodies in the dissection course were decapitated young healthy males (von Ditfurth, 1993; p 167), whereas Hans Harald Bräutigam, also a student of Stieve's, described young apparently healthy female bodies for dissection which showed strangulation marks in the neck region (Bräutigam, 1998; p 8). von Ditfurth stated that it was no secret at all why these persons had been executed, as every execution was publicly announced, including a statement concerning the reason for the verdict of capital punishment (von Ditfurth, 1993; p 167).

A rather bizarre chapter of medical training in NS Germany relates to a group of Norwegian medical students, who belonged to a total of 1,200 medical students who were taken as prisoners in Oslo. Some of them were housed in the concentration camp Buchenwald to be trained as SS officials. There they received medical training through lectures by professors from the University of Jena and were supervised in anatomical dissection and histology by other prisoners in the camp. A Norwegian economy student, imprisoned at the same time in Buchenwald, noted in his diary on August 4, 1944, that the medical students were able to make the "best use" of their stay in Buchenwald in terms of their professional training, as there was never a lack of dissection material (Hirte and Stein, 2003; p 383-388).

\section{The Roots of Racial Hygiene in Germany}

In the late 19th and early 20th century, the field of anatomy was closely associated with physical anthropology, eugenics, and the emerging science of genetics. The development of the relationship between these disciplines and anatomy up to and during the Third Reich is largely unexplored. Physical anthropology had developed as a subdiscipline of anatomy in the middle of the 19th century and its objective was to describe the physical and physiological characteristics of human beings and their varieties, often called races. Some early anthropologists thought the term race not applicable biologically to these human varieties because Darwinian biology postulated a single human race that caused variations, not races (Weindling, 1989; p 49; Lösch, 1997; Schafft, 2004; p 202/203). Rudolf von Virchow and his anthropological colleagues accepted the concept of race as "hereditary variation," but specifically denied the existence of fixed racial types 
or the superiority of certain races (Weindling, 1989; p 48/49, 55). However, many others considered Rassenkunde, the science of race, an essential part of anthropology. With the growing influence of the ideas of nationalism, racism, and Aryan supremacy as advanced by authors like Arthur de Gobineau, some younger anthropologists and eugenicists embraced the concept of race and applied it to apparent physical varieties of humans (e.g., Bergmann et al., 1989). Alfred Ploetz saw the category of race as the foundation of the discipline of eugenics, a social-Darwinist concept envisioned by Francis Galton. Eugenic ideas were based on the theories of evolution and human inheritance, as proposed by August Weismann, and were concerned with the hereditary quality of "human stock" (Weingart, 1989; Fangerau and Noack, 2006). Eugenics was thought to be the only effective therapy against the perceived threat of an inevitable degeneration of civilized humankind. Eugenic thinking promoted the negative selection, i.e., elimination, of those seen as "unfit" for society and positive selection for those seen as "fit." In the first decades of the 20th century, eugenics was considered a progressive science around the world, and eugenic ideas of negative selection, like sterilization of certain groups of society, were applied to legislature, for example in the United States (Black, 2003) and Sweden (Weigmann, 2001). Beginning in 1895, Ploetz called his concept of eugenics, based on Wilhelm Schallmeyer (Ritter, 1992), racial hygiene and founded the worldwide first eugenic society, the Deutsche Gesellschaft für Rassenhygiene (German Society for Racial Hygiene) in 1904 (Klee, 2003; Fangerau and Noack, 2006). His perception of race included not only specific physical, but also cultural characteristics of humans and implied the superiority of Nordic races (Weingart et al., 1988; p 91ff). The term racial hygiene instead of eugenics was generally used in Germany, and after the First World War many German racial hygienist increasingly included the ideas of the supremacy of the Northern and Aryan races as well as anti-Semitism in their thinking (Schafft, 2004; p 205-207).

The turn of the century had brought the rediscovery of Mendel's laws of genetics for botany and rare human diseases. Also, Gertrude and Charles Davenport had declared to have found proof for Mendelian inheritance in normal human traits, such as hair form, hair color, and eye color (Davenport and Davenport, 1907, 1908, 1909). These developments encouraged Eugen Fischer, an anatomist and physical anthropologist from Freiburg, to apply Mendelian laws to so-called "racial traits," among which he counted hair color and shape, eye color and shape, skin color and skull shape. In a field study begun in 1908 and published in 1913, he collected data from a population of so-called "bastards" in Rehoboth, South-West Africa, the offspring of an inhomogeneous group of white men and their African female partners (Fischer, 1913). Even though his raw data and statistics were ambiguous, Fischer claimed that they gave proof to the inheritance of race by Mende- lian laws. At the same time, he commented extensively on the inferiority of Africans in terms of character and intelligence. With this report on the "Rehoboth Bastards" Fischer became the founder of a new science called racial biology. A closer look at his data shows that they did not hold up to Fischer's claim (Mai and Bussche, 1989; Lösch, 1997). Indeed, they could not, as first Fischer did not differentiate between phenotype and genotype. Second, the parent populations were not homogenous, a fundamental requirement for Mendelian analysis. Third, Mendelian inheritance in man can be phenotypically observed in monogenic disease, but the characteristics Fischer had chosen were multigenic. He could have known that the latter was a problem had he read the article published by the geneticist Wilhelm Weinberg in 1908, in which Weinberg had pointed out that a proof for Mendelian inheritance in humans is only possible for rare, exceptional traits (Lösch, 1997; p 70). Such rare human characteristics had first been described and linked to Mendelian inheritance by Archibald Garrod in 1902, in his work on the monogenic disease alkaptonuria and later for other inborn errors of metabolism (Garrod, 1902, 1908). However, a critical reading of Davenport and Davenport reveals the same weaknesses in their data sets as in Fischer's, i.e., shaky statistics and arbitrary definition of traits. Despite the weakness of the data, the concept of Mendelian inheritance of racial characteristics, physical, and psychological ones was seen as scientifically proven thereafter, and Fischer, who had also joined Ploetz' society, became known as a preeminent racial hygienist and an expert on racial genetics. Formerly a prosector at the anatomical department of Freiburg, he was promoted to chairman of anatomy in Freiburg in 1918. In 1927, he moved to Berlin as the director of the newly founded Kaiser-Wilhelm-Institute for Anthropology, Human Heredity, and Eugenics (Grüttner, 2004), which later played a central role in NS eugenic policies.

In the 1920s, the disciplines of racial hygiene and Vererbungslehre (the science of inheritance, i.e., human genetics) were being taught by anatomists, anthropologists, hygienists, and biologists as part of the mandatory medical curriculum. At the same time, many institutes of racial hygiene were founded at German universities or as independent research institutes (Weingart et al., 1988; p 438; Ritter, 1992; p 176/177; Fangerau and Noack, 2007). The first standard text on racial hygiene and inheritance was written in 1923 by the botanist and physician Erwin Baur, the anatomist Eugen Fischer, and the physician Fritz Lenz, a pupil of Ploetz (Baur et al., 1923). By the end of the 1920s racial hygiene/ human genetics and experimental genetics had separated into two distinct disciplines in Germany, with the latter focusing on basic and often innovative scientific research (Weingart, et al., 1988; p 334/335; Roth, 1999; p 411), and racial hygiene becoming increasingly focused on eugenic social policies (Weingart et al., 1988; p 351ff). These policies included sterilization for eugenic purposes and premarital eugenic counseling. Anthropological meth- 
ods, including family and twin research, were the prime methodology in German racial hygiene after the Mendelian approach as used by Fischer had shown little promise. Newer genetic research results were not integrated into racial hygienic thinking throughout the 1930s (Weingart, 1989; p 345ff, 355; Roth, 1999; p 405), as there was little communication between German experimental geneticists and racial hygienists until 1939. Then Otmar von Verschuer emphasized the need for the inclusion of innovative genetic insights in racial hygienic concepts (Kröner, 1998; Roth, 1999; p 348).

As early as 1927 criticism was leveled at the subject of racial hygiene by the American eugenicist Raymond Pearl, who contended that the literature of eugenics had "developed into a mix of badly argued and uncritical sociology, economy, anthropology, and politics full of emotional appeals to class- and race-stereotypes, solemnly presented as science and unfortunately accepted as such by the public" (translation by author, quoted from Weingart et al., 1988; p 316/317). Karl Saller also criticized the lack of evidence for certain allegedly inherited traits like beauty (Weingart et al., 1988; p 317/318), and the fact that the commonly accepted concept of racial hygiene in Germany did not allow for a dynamic development of races, for example, through environmental influences (Beushausen, 1998; Schafft, 2004; p 227-230). At the same time, German politics in the Weimar republic was increasingly open for the introduction of eugenic ideas in legislation (Schmuhl, 1987; Kröner, 1998), and the growing NS movement promoted the concepts of racial hygiene eagerly. Weingart summarizes that, "Scientists used eugenics as a vehicle for their political convictions and social biases, just as politicians used its scientific framework, sketchy as it was, to advance their particular causes" (Weingart, 1989; p 260).

\section{Anatomists and Racial Hygiene in NS-Germany}

Adolf Hitler had read the Baur-Fischer-Lenz as a source for his book "Mein Kampf" (1925/1926) and incorporated topics of racial hygiene amalgamated with anti-Semitism into his political arguments. The concept of static genetic traits and races unalterable by environmental influences was the purported scientific foundation for the racism pervading NS ideology and NS policies (Lifton, 1986; Geiss, 1988; Weingart, 1989; p 372/373; Schafft, 2004). In 1934, Hitler's deputy Rudolf Hess declared National Socialism to be "applied biology," a term first coined by Fritz Lenz in 1931 (Proctor, 2000), and promoted racial hygiene as the only possible therapy for a Nordic people threatened by degeneration. The individual human being was seen only as part of the total body of the people (Volkskörper), thus allowing the removal of "diseased" individuals as a drastic but necessary cure to save the health of the body of the people (Volksgesundheit). Because of this biologistic definition, the term "diseased" in National Socialism included not just the physically sick, but also those deemed genetically, racially and socially "unfit" for the new society: the mentally ill, children born with malformations, homosexuals, social misfits, political opponents, certain religious groups, and so-called "non-Aryan" racial groups like Jews, Sinti, and Roma (European gypsies). They all could be subjected to the different methods of negative selection that included sterilization, so-called euthanasia and mass murder (Platen-Hallermund, 1948; Klee, 1985; Lifton, 1986; Weingart et al., 1989; Bäumer, 1990; Proctor, 1994; Kröner, 1996; Seidelman, 1996).

Racial hygienists welcomed the National Socialists' rise to power because they saw a bright future for the implementation of their eugenic policies (Ritter, $1992 ;$ p 177/178). In 1933, the anatomist Eugen Fischer, who had just been elected rector of Berlin University and in this role had signed the dismissal of his "non-Aryan" colleagues, praised the "biological population politics" of the new NS regime, which used selection and Ausmerzung (a term that can mean elimination as well as destruction) to create a genetically and racially desirable population (MüllerHill, 1984; p 13/14). Again in 1943, Fischer recapitulated the preceding 10 years by pointing out the great good fortune of his theoretical science having prospered in an atmosphere of general acceptance fostered by NS ideology. He lauded the practical application of racial hygiene's "scientific results" in governmental procedures (Hofer and Leven, 2003; p 27). Racial hygienists including Fischer, von Verschuer, and the psychiatrist Ernst Rüdin were active in evaluations for so-called Genetic Health Courts (Ritter, 1992; p 183; Proctor, 1994; Kröner, 1998), drawing up testimonies about an individual's racial and genetic heritage, thus contributing to the justification of racial discrimination, physical mutilation (involuntary sterilization), expulsion, and murder (Müller-Hill, 1984, Massin, 1999; p 41).

Anatomists frequently worked and taught in the related fields of anthropology, human inheritance, and racial hygiene. Many had made their career in these areas after the First World War, among them were Karl Saller of Göttingen (Beushausen, 1998), Franz Weidenreich of Heidelberg (Eckart et al., 2006), Heinrich Poll of Hamburg (Rothmaler, 1990), Walter Brandt of Köln (Blaschke et al., 1988), Ferdinand Wagenseil of Giessen (Unger, 1998), Eugen Kurz, and Johann Paul Kremer of Münster (MünsterVorlesungsverzeichnis, 1932-1939; Vieten, 1983). Saller and Weidenreich ran into political trouble because they adhered to a dynamic concept of race and disagreed with the official NS line of static races. They were both dismissed, Weidenreich with the additional reason of being a Jew. Also dismissed were Poll and Brandt, Poll because he was a Jew and Brandt for being married to a Jewish woman. The National Socialists Kurz and Kremer continued teaching and publishing on racial hygienic topics in the 1930s (Münster-Vorlesungsverzeichnis, 1932-1939; Vieten, 1983; Dicke, 2004). Kremer, who also taught genetics, believed to have found proof for the heritability of traumatically acquired traits (cats with stumpy tails), a theory that brought him some ridicule from his colleagues (Höss et al., 1984; p 200, 233, 235). Wilhelm Pfuhl of Greifswald, Kurt Aichel of Kiel, 
Otto Grosser of Prague, and Heinrich von Hayek and Enno Freerksen in Rostock taught racial hygiene as part of the required medical curriculum (GreifswaldVorlesungsverzeichnis, 1933-1939; Kiel-Vorlesungsverzeichnis, 1933-1938; Arndt, 1967; Hlavácková and Mísková, 2001).

Other anatomists started to focus on research on racial hygienic topics when it became politically advantageous to do so, e.g., August Hirt. Another example is Friedrich Heiderich, chairman of the anatomical department of Münster University, who established a new division of racial hygiene and human genetics within his institute by 1939, supported Kurz and Kremer in their work and promoted racial studies of the local population (Dicke, 2004; $p$ 37-39). There is only one report of an anatomist, Ferdinand Wagenseil, giving up his racial hygienic research because of the discipline's exploitation by the NS-regime. He had performed anthropological studies on Jews in Turkey and Chinese populations during his tenure at Tung-Chi University in Shanghai. On his return from China to NS Germany he was disgusted with what he considered the "perversion of anthropology" by official NS doctrine and decided to start in a new field of research in cell biology (Unger, 1998; p 95).

\section{Other Medical Disciplines Using the Bodies of NS Victims}

Besides anatomy, other medical disciplines made use of the bodies of victims of the NS regime for research. Among them were forensic medicine, pathology, and genetics (Herber, 2002; Prüll, 2003; Babaryka, 2008). The racial hygienist, geneticist, and hereditary pathologist Otmar von Verschuer was famous for his twin research. He used his scientific renown to make pronouncement on Jewish "racial characteristics" that contributed to the so-called scientific legitimation of NS anti-Jewish policies (MüllerHill, 1984; Ehrenreich, 2007). In 1943/44, von Verschuer employed his former postdoctoral student Josef Mengele as an assistant at the Kaiser Wilhelm Institute for Anthropology, Berlin. During this time Mengele also worked as an Schutzstaffel physician at the concentration camp in Auschwitz, where he experimented on human subjects. From there he provided blood samples for Verschuer's institute from "very diverse racial groups," "eyes from murdered Gypsies," internal organs from murdered children, two skeletons from Jews, and sera from twins, who had been infected with typhoid by Mengele. Von Verschuer and his colleagues used 200 blood samples from Auschwitz to determine the heritability of certain proteins. They also used eyes sent from Auschwitz to investigate the inheritance of eye-color. Both projects were funded by the German Research Foundation (Müller-Hill, 1984; p 24; Bergmann et al., 1989; p 137; Kröner, 1998; p 53; Ehrenreich, 2007; p 66).

Neuropathology was another discipline that profited greatly from the increased availability of human "material," specifically as a result of the NS euthanasia program. During the Second World War, an esti- mated 120,000 handicapped children and adults were murdered and many of their brains used for research by neuropathologists. One of the most prominent among them was the psychiatrist and neuropathologist Julius Hallervorden of the KaiserWilhelm-Institute for Brain Research in Berlin. He was also the prosector and medical examiner at the psychiatric hospital and later euthanasia center in Brandenburg-Görden and several other Berlin institutions. Hallervorden had heard about the secret euthanasia plans, which he did not support, but used the brains harvested from the victims of these killings for further research. He provided the clinical institutions, where the murders were perpetrated, with fixatives, jars and instructions for removing and fixing the brains, and was able to study a total of 697 brains histopathologically (Müller-Hill, 1984; Peiffer, 1997; Klee, 2003; Peiffer, 2004; p 104, 147-151; Aly, 2005; Hughes, 2007; p 119). His colleagues Hans Joachim Scherer, Breslau, and Berthold Ostertag, Berlin, also used brains from children killed in the euthanasia program for their research purposes (Peiffer, 1997). In June 1941 Heinrich Gross, attending physician at the Vienna psychiatric hospital "Am Spiegelgrund," visited Görden for a training session to learn the techniques of euthanasia. Subsequently 336 children died under his care until he was called to military service in 1943 . He again worked at "Spiegelgrund" in 1944. Tissues from the children's bodies were still stored after the war, and Gross started publishing the results of his histopathological work in 1952. Brains from "Am Spiegelgrund" were used for scientific studies until 1978 (Neugebauer, 1997; Spann, 1999; Czech, 2002).

\section{The Case of Konrad Lorenz, Anatomist and Ethologist}

Konrad Lorenz, ethologist and Noble laureate, studied medicine and zoology at the University of Vienna in the 1920s and became assistant at the anatomical department under Ferdinand Hochstetter in 1931. He supervised the medical students' anatomical dissections and was responsible for the preparation and collection of specimens. At the same time, he pursued his psychological studies of animals, a work supported by Hochstetter. When Hochstetter retired in 1934, the National Socialist Eduard Pernkopf became his successor. Pernkopf demanded full attention to his anatomical duties from Lorenz, who decided to continue pursuing his interests in ethology and subsequently lost his anatomical position in 1935. Lorenz then tried to earn money with a series of popular talks on ethology and started applying for funding by the German Research Foundation (Föger and Taschwer, 2001; Taschwer and Föger, 2003). He finally received this funding in 1938, after providing testimonies to his racial, professional, and political character from, among others, the anatomists Hochstetter, Pichler, and Pernkopf. Pichler vouched for Lorenz' "growing interest in National Socialism," and that his biological studies were in keeping with the world view prevailing in the Third Reich (Dei- 
chmann, 1996; Burkhardt, 2005). Indeed, many of the principles on which Lorenz' ethology was based came from the same ideological roots as the ideas of racial hygiene promoted in NS Germany. Examples are his pronouncements on the degeneration in human beings and animals, his social-Darwinist view of biology and society (Kalikow, 1983; p 39, 40) or his statement that social "morality" in humans is to the greatest extent inborn (Burkhardt, 2005; p 243). By applying animal behavior to racial hygiene, he commented that the danger to a race lay in the undesirable types that proliferated under the conditions of civilization, and concluded in 1938: "Nothing is more important for the health of an entire people than the elimination of invirent types, which, with the most dangerous and extreme virulence, threaten to penetrate the body of a people like the cells of a malignant tumor" (Burkhardt, 2005; p 244).

Lorenz, like many other scientists, greatly welcomed the annexation of Austria by NS Germany in 1938 and joined the NSDAP (the NS political party, Nationalsozialistische Deutsche Arbeiterpartei; Klee, 2003). He hoped to gain additional funding for his work and new bright colleagues to work with. In a series of articles published from 1938 to 1943 he argued, "that the degeneration of instinctive behavior patterns in domesticated animals paralleled a breakdown in the instinctive behavior patterns of humans in civilized society" (Burkhardt, 2005; p 249). Lorenz' career prospered, and in 1940 he became chairman of psychology at the University of Königsberg (Burkhardt, 2005). He was called to military service in 1941 and started working as a military psychiatrist in Posen in 1942. There he collaborated in a study on racial psychology led by the psychologist Rudolf Hippius, who investigated the moral character in the offspring of mixed German and Polish marriages. The results claimed to proof the moral superiority of subjects with a greater admixture of "German blood." It is unclear if Lorenz' participation in this study was voluntary. In 1943 or 1944, Lorenz saw for the first time a transport of concentration camp prisoners, Gypsies, in the vicinity of Posen and he later declared that this was the moment when he first realized the extent of the crimes the NS regime committed against humanity (Föger and Taschwer, 2001).

\section{DISCUSSION}

The review of now available literature shows that all anatomical departments in NS Germany without exception used the bodies of the executed and frequently of other NS victims. It had been questioned whether the anatomical institute in Rostock had used bodies of the executed (Schumacher and Wischhusen, 1970; Rothmaler, 1990; p 87), but newer information from original documents shows that Kurt Neubert made use of them as soon as he had the necessary personnel available (Neubert, 1941; Noack, 2007; p 16). Although the bodies of the executed had historically been a common source for anatomical dissections in Germany and many other countries, the NS policies led to an unprecedented increase in their numbers.
The identification of the victims shows that their origins were much more varied than originally assumed for example in the Pernkopf controversy, where correspondents feared that mostly Jewish bodies had been used for anatomical purposes (Hildebrandt, 2006). Although there were several Jews among the victims, a majority consisted of Germans of so-called "Aryan" descent, who were opposed to the regime, as well as forced laborers and prisoners of war from Poland and Russia and many other countries. At this point in time, some of these individuals have been identified, even as late as 60 years after the fact (e.g., Lang 2007). Further efforts are necessary to give names to as many of them as possible, as Cahill contends that we have no right to draw analogies from this history for our own lives "until we have registered the magnitude and the dignity of each life destroyed," fulfilling the "primordial moral task [...] to listen" (Cahill, 1994).

It is hard to judge if the anatomists felt any sympathy with the persons who ended up as bodies in their departments, as so far there have been no public statements found that attested to such feelings. There is only one record of an anatomist reacting compassionately to the increase of executions and the fate of the victims, and who deplored the attitude of another anatomist. A colleague reported that Ferdinand Wagenseil, chairman of the anatomical department at the University of Giessen, was deeply shocked by a letter from Hermann Stieve, who had written to him about his research on a series of bodies of female prisoners executed for high treason (Schmidt, 1993; p 114). He shared his horror about the provenance of the bodies with his colleagues and students. Nevertheless, Wagenseil, like all of his colleagues, used the bodies of the executed for dissection (Oehler-Klein, 2007; p 369). It has to be stated that this use of the bodies of victims of the NS regime was independent of the anatomists' political views. Stöhr, Benninghoff, von Möllendorf, and Stieve were all not friends of the NS regime, but accepted these bodies the same as their NS politically active colleagues (von Möllendorf, 1942; Grundmann and Aumüller, 1996; Forsbach, 2006; Noack, 2007). This is probably due to the fact that, the bodies had been a traditional source for dissection over centuries. However, it has to be asked if not the sheer amount of them should have given rise to new questions in the minds of the anatomists. With respect to the medical students, their experiences in the dissection rooms may have been part of the motivation that led to political opposition within their ranks, including some of the students constituting the Weisse Rose (White Rose) resistance group (Bussche, 1989; p 156/157 and 173/174). The same may also apply to Renate Roese, a student of Wagenseil's in Giessen, who was horrified by the "new material" and was later imprisoned for political opposition (Schmidt, 1993; p 136; Oehler-Klein, 2007; p 369).

A first exploration of the connection between anatomists and racial hygiene shows that many anatomists were part of the racial hygienic movement that in its foundations was a pseudoscience 
and served as a scientific justification to the eugenic NS policies. Some anatomists in their role as racial hygienists helped facilitate sterilization und ultimately mass murder, whereas others became victims of their own science in that they were dismissed for racial reasons. After the war, most of the prominent NS racial hygienists claimed that they had not understood the extent to which their work had contributed to the destruction of human lives wrought by the NS-regime, or that their science had been misinterpreted and misused. Several of them continued their careers as professors of human genetics in postwar Germany, among them Fritz Lenz in Göttingen and Otmar von Verschuer in Münster. Eugen Fischer was retired by then (Müller-Hill, 1984; Weindling, 1989; p 567; Kröner, 1998; Massin, 1999; Grüttner, 2004).

Other related medical disciplines also made use of NS victims, especially neuropathology. Julius Hallervorden's NS political involvement has become widely known in recent years, leading to the renaming of Hallervorden-Spatz syndrome as NBIA1 (neurodegeneration with brain iron accumulation 1) or pantothenate kinase-associated neurodegeneration, respectively (Harper, 1996; OMIM \#234200, 2009).

In the case of Konrad Lorenz it is difficult to tell whether he would have focused on racial degeneration and other NS racial biology topics that were easily applicable within his own theories if the political climate had been different (Kalikow, 1983; p 55). As it was, he, the former anatomist, acted like many of his fellow anatomists and other academics: he made use of the special opportunities the NS regime gave him.

\section{REFERENCES}

Aly G. 1994. The Posen diaries of the anatomist Hermann Voss. In: Aly G, Chroust P, Pross C, editors. Cleansing the Fatherland. Nazi Medicine and Racial Hygiene. Baltimore: The Johns Hopkins University Press. p 99-155.

Aly G. 2003. Rasse und Klasse. Nachforschungen zum deutschen Wesen. Frankfurt am Main: S. Fischer Verlag GmbH. p 1-254.

Aly G. 2005. Macht-Geist-Wahn. Kontinuitäten deutschen Denkens. Frankfurt am Main: Fischer Taschenbuch Verlag. p 73-93.

Angetter DC. 2000. Anatomical Science at University of Vienna 1938-45. Senate Project of the University of Vienna. Lancet 355:1454-1457.

Arbogast $\mathrm{CH}$. 1998. Herrschaftsinstanzen der Württembergischen NSDAP: Funktion, Sozialprofil und Lebenswege einer Regionalen NS-Elite 1920-1960. München: Oldenbourg. p 1-295.

Arndt R. 1967. Die Entwicklung der Anatomie zu Rostock von 1870 bis zur Gegenwart, Dissertation. Rostock. p 1-73.

Aumüller G. 1991. Die Anatomie in der NS-Zeit. In: Fachschaft Medizin der Philipps-Universität Marburg: "bis der langersehnte Umschwung kam." Marburg: Von der Verantwortung der Medizin unter dem Nationalsozialismus. p 87-112.

Aumüller G, Grundmann K, Krähwinkel E, Lauer H, Remschmidt H. 2001. Die Marburger Medizinische Fakultät im "Dritten Reich." München: K.G. Saur. p 1-736.

Babaryka G. 2008. Das pathologische Institut der Universität München in der Ära Max Borst von 1910 bis 1946. In: Kraus E, editor. Die Universität München im Dritten Reich. Aufsätze. Teil II. München: Herbert Utz Verlag. p 63-132.

Bäumer A. 1990. NS-Biologie. Stuttgart: S. Hirzel Wissenschaftliche Verlagsgesellschaft. p 91-102:214.

Bargmann W. 1942. Über Kernsekretion in der Neurohypophyse des Menschen. Z Zellforsch 32:394-400.
Bargmann W, Scheffler A. 1943. Über den Saum des menschlichen Darmepithels. Z Zellforsch 33:5-13.

Bauer K. 1940. Über das Grundnetz der menschlichen Grosshirnrinde. Z Zellforsch 30:751-768.

Baur E, Fischer E, Lenz F. 1923. Menschliche Erblichkeitslehre und Rassenhygiene. München: J.F. Lehmanns Verlag. p 1-442.

Bembenek L, Schumacher F. 1980. Nicht alle sind tot, die begraben sind. Widerstand und Verfolgung in Wiesbaden 1933-1945. Frankfurt am Main: Röderberg-Verlag. p 1-456.

Bergmann A, Czarnowski G, Ehmann A. 1989. Menschen als objekte humangenetischer Forschung und Politik im 20. Jahrhundert. In: Ärztekammer Berlin, editors. 1989. Der Wert des Menschen: Medizin in Deutschland 1918-1945. Berlin: Edition Hentrich. p 121-142.

Beushausen U, Dahms H-J, Koch T, Massing A, Ortmann K. 1998. Die medizininsche Fakultät im dritten Reich. In: Becker $\mathrm{H}$, Dahms H-J, Wegeler C, editors. Die Universität Göttingen unter dem Nationalsozialismus. München: K.G. Saur. p 183-286.

Black E. 2003. War Against the Weak. Eugenics and America's Campaign to Create a Master Race. New York: Four Walls Eight Windows. p 1-550.

Blaschke W, Hensel O, Liebermann P, Lindweiler W. (eds.) 1988. Nachhilfe zur Erinnerung, 600 Jahre Universitäet Köeln. Bonn: Pahl-Rugenstein. p 1-288.

Bräutigam H. 1998. Beruf: Frauenarzt. Erfahrungen und Erkenntnisse eines Gynäkologen. Hamburg: Hoffmann und Campe. p 1-255.

Brysac SB. 2000. Resisting Hitler. Mildred Harnack and the Red Orchestra. Oxford: Oxford University Press. p 1-498.

Burkhardt RW Jr. 2005. Patterns of Behavior. Konrad Lorenz, Niko Tinbergen, and the Founding of Ethology. Chicago: University of Chicago Press. p 1-648.

Bussche H van den. 1989. Im Dienste der "Volksgemeinschaft": Studienreform im Nationalsozialismus am Beispiel der ärztlichen Ausbildung. Berlin/Hamburg: Dietrich Reimer Verlag. p 1-261.

Cahill LS. 1994. Lessons we have learned. In: Michalczyk JJ, editor. Medical Ethics and the Third Reich: Historical and Contemporary Issues. Kansas City: Sheed \& Ward. p 213-216.

Czech H. 2002. Der Fall Heinrich Gross. Die wissenschaftliche Verwertung der "Spiegelgrund"-Opfer in Wien. Risse im Context XXI. 2002. URL: http://www.contextxxi.at/context/content/ view/164/93/ [Accessed January 2009].

Davenport GC, Davenport CB. 1907. Heredity of eye-color in man. Science New Series 26:589-592.

Davenport GC, Davenport CB. 1908. Heredity of hair-form in man. Am Natural 42:341-349.

Davenport GC, Davenport CB. 1909. Heredity of hair color in man. Am Natural 43:193-211.

Deichmann U. 1996. Biologists Under Hitler. Cambridge: Harvard University Press. p 1-468.

Dicke JN. 2004. Eugenik und Rassenhygiene in Münster. Berlin: Weissensee Verlag. p 1-167.

Drews U. 1992. Die Zeit des nationalsozialismus am anatomischen institut in Tübingen: Unbeantwortete ethische Fragen damals und heute In: Peiffer J, editor. Menschenverachtung und Opportunismus. Zur Medizin im Dritten Reich. Tübingen: Attempto. p 93-107.

Druml W. 1999. "Fortschritt kann nur entstehen aus einer umfassenden Präsenz des Vergangenen." Editorial. Wien Klin Wochenschr 111:739-740.

Eckart WU, Sellin V, Wolgast E. 2006. Die Universität Heidelberg im Nationalsozialismus. Heidelberg: Springer. p 1-1278.

Ehrenreich E. 2007. Otmar von Verschuer and the "Scientific" legitimization of the Nazi Anti-Jewish Policy. Holocaust Genocide Stud 21:55-72.

Fangerau J, Noack T. 2006. Rassenhygiene in Deutschland und Medizin im Nationalsozialismus. In: Schulz S, Steigleder K, Fangerau H, Paul NW, editors. Geschichte, Theorie und Ethik der Medizin. Eine Einführung. Frankfurt am Main: Suhrkamp. p 224-246.

Ferner H. 1940. Über den Bau des Ganglion semilunare (Gasseri) und der Trigeminuswurzel des Menschen. Z Anat Entw 110:391-404.

Fischer E. 1913. Die Rehobother Bastards und das Bastardisierungsproblem beim Menschen. Jena: Verlag Gustav Fischer, Jena. p 1-324. 
Fleischer H. 1940. Über ein regelmässig vorhandenes Ganglion accessorium trigemini und seine Lage im Cavum trigemini. Z Anat Entw 110:755-766.

Föger B, Taschwer K. 2001. Die andere Seite des Spiegels. Konrad Lorenz und der Nationalsozialismus. Wien: Czernin Verlag. p 1-352.

Form W, Schiller Th. 2005. Politische Justiz in Hessen. Die Verfahren des Volksgerichtshofs, der politischen Senat der Oberlandesgerichte Darmstadt und Kassel 1933-1945 sowie Sondergerichtsprozesse in Darmstadt und Frankfurt/M. (1933/34). N.G. Marburg: Elwert Verlag, Marburg. p 1-1165.

Forsbach R. 2006. Die Medizinische Fakultät der Universität Bonn im "Dritten Reich." München: R. Oldenbourg Verlag. p 1-767.

Garrod A. 1902. The incidence of alkaptonuria: A study in chemical individuality. Lancet 160:1616-1620.

Garrod A. 1908. The Croonian lectures on inborn errors of metabolism. Lancet 172:1-7.

Geiss I. 1988. Geschichte des Rassismus. Frankfurt am Main: Suhrkamp. p 1-374.

Greifswald-Vorlesungsverzeichnis: Vorlesungsverzeichnisse der Universität Greifswald 1933 bis 1939.

Grün B, Hofer H-G, Leven K-H. (eds.) 2002. Medizin und Nationalsozialismus. Die Freiburger Medizinische Fakultät und das Klinikum in der Weimarer Republik und im "Dritten Reich." Frankfurt am Main: Peter Lang Verlag. p 1-544.

Grüttner M. 2004. Biographisches Lexikon zur Nationalsozialistischen Wissenschaftspolitik. Heidelberg: Synchron Wissenschaftsverlag der Autoren. p 1-215.

Grundmann K, Aumüller G. 1996. Anatomen in der NS-Zeit: Parteigenossen oder Karteigenossen? Das Marburger anatomische Institut im Dritten Reich. Medizinhist J 31:322-357.

Halbrainer H. 2000. Widerstand und Verfolgung in der Steiermark während der Zeit des Nationalsozialismus. "Er hat dem Teufel den Eid nie geschworen" Franz Dollnig-Der steirische Franz Jaegerstätter. URL: http://home.sprit.org/clio/www.clio-graz.net/ wider/dollnig1.html [Accessed March 2009].

Harper PS. 1996. Naming of syndromes and unethical activities: The case of Hallervorden and Spatz. Lancet 348:1224-1225.

Herber F. 2002. Gerichtsmedizin unterm Hakenkreuz. Leipzig: Militzke. p 1-541.

Hett J. 1943. Becherzellpolster in den Speicheldrüsenausfuehrungsgängen (submandibularis des menschen) Z Zellforsch 32:335-338.

Hildebrandt S. 2006. How the Pernkopf controversy facilitated a historical and ethical analysis of the anatomical sciences in Austria and Germany: A recommendation for the continued use of the Pernkopf atlas. Clin Anat 19:91-100.

Hildebrandt S. 2008. Capital punishment and anatomy: History and ethics of an ongoing association. Clin Anat 21:5-14.

Hirte R, Stein H. 2003. Die Beziehungen der Universität Jena zum Konzentrationslager Buchenwald. In: Hossfeld $U$, John J, Lemuth $O$, Stutz R, editors. "Kämpferische Wissenschaft." Studien zur Universität Jena im Nationalsozialismus. Köln: Böhlau Verlag. p 361-400.

Hlavácková L, Mísková A. 2001. Otto Grosser (1873-1951) Mediziner. Vom überzeugten Nationalisten zum aktiven Nationalsozialisten. In: Glettler M, Mísková A, editors. Prager Professoren 1938-1945. Zwischen Wissenschaft und Politik. Essen: Klartext Verlag. p 415-428.

Hofer H-G, Leven K-H. 2003. Die Freiburger Medizinische Fakultät im Natinoalsozialismus. Katalog einer Ausstellung des Instituts für Geschichte der Medizin der Universität Freiburg. Frankfurt: Peter Lang. p 1-135.

Höss R, Broad P, Kremer JP. 1984. KL Auschwitz seen by the SS. Selection, Elaboration and Notes by Bezwinska, Jadwiga and Czech, Danuta. New York: Howard Fertig.

Hughes JT. 2007. Neuropathology in Germany during World War II: Julius Hallervorden (1882-1965) and the Nazi programme of "euthanasia." J Med Biogr 15:116-122.

Huter F. (ed.) 1970. Hundert Jahre Medizinische Fakultät Innsbruck 1869-1969. II. Teil. Geschichte der Lehrkanzeln, Institute und Kliniken. Innsbruck: Universität Innsbruck.

Jakobi H, Chroust P, Hamann M. 1989. Äskulap und Hakenkreuz. Zur Geschichte der Medizinischen Fakultät in Giessen zwischen 1933 und 1945. Frankfurt: Mabuse-Verlag. p 1-202.
Kalikow TJ. 1983. Konrad Lorenz's ethological theory: Explanation and ideology, 1938-1943. J Hist Biol 16:39-73.

Kiel-Vorlesungsverzeichnis: Christian-Albrechts Universität Kiel. Personal- und Vorlesungsverzeichnisse 1933-1938.

Klee E. (ed.) 1985. Dokumente zur Euthanasie. Frankfurt am Main: Fischer Taschenbuchverlag GmbH. p 1-342.

Klee E. 2003. Das Personenlexikon zum Dritten Reich. Wer war was vor und nach 1945? Frankfurt am Main: S. Fischer. p 1-731.

Kröner HP. 1996. Die umgestaltung der ethik: Das los zukünftiger Generationen und die "Volksgemeinschaft." In: Kolb S, editor. Fürsorge oder Vorsorge: Medizin zwischen Patientenwohl and Volksgesundheit. Frankfurt am Main: Fischer Taschenbuchverlag GmbH. p 47-64.

Kröner HP. 1998. Von der Rassenhygiene zur Humangenetik. Stuttgart: Gustav Fischer Verlag. p 1-311.

Lang H-J. 2007. Die Namen der Nummern. Wie es gelang, die 86 Opfer eines NS-Verbrechens zu identifizieren. Überarbeitete Ausgabe. Frankfurt am Main: S. Fischer Verlag. p 1-303.

Lawrynowicz K. 1999. Albertina. Zur Geschichte der Albertus-Universität zu Königsberg in Preussen. Berlin: Duncker und Humblot. p 1-519.

Lifton RJ. 1986. Ärzte im Dritten Reich. German Edition 1998. Berlin: Ullstein Buchverlag GmbH \& Co KG. p 1-656.

Lösch NC. 1997. Rasse als Konstrukt. Leben und Werk Eugen Fischers. Frankfurt: Peter Lang GmbH. p 1-615.

Mai C, Bussche $\mathrm{H}$ van den. 1989. Die Forschung. In: van den Bussche $H$, editor. Medizinische Wissenschaft im "Dritten Reich." Kontinuität, Anpassung und Opposition an der Hamburger Medizinischen Fakultät. Berlin/Hamburg: Reimer Verlag. p 165266.

Malina P, Spann G. 1999. Das Senatsprojekt der Universität Wien "Untersuchungen zur anatomischen Wissenschaft in Wien 19381945." Wien Klin Wochenschr 111:743-753.

Massin B. 1999. Anthropologie und humangenetik im nationalsozialismus oder: Wie schreiben deutsche Wissenschaftler ihre eigene Wissenschaftsgeschichte? In: Kaupen-Haas $\mathrm{H}$, Saller $\mathrm{CH}$, editors. Wissenschaftlicher Rassismus. Analysen einer Kontinuität in den Human- und Naturwissenschaften. Frankfurt: Campus Verlag, Frankfurt. p 12-64.

Mörike KD. 1988. Geschichte der Tübinger Anatomie. Tübingen: JCB Mohr (Paul Siebeck). p 1-188.

Müller-Hill B. 1984. Tödliche Wissenschaft. Reinbek bei Hamburg: Rowohlt Taschenbuch Verlag. p 1-188.

Münch H-G. 1978. Das Anatomische Institut in Würzburg von 19251966, Dissertation. Würzburg.

Münster-Vorlesungsverzeichnis: Personal- und Vorlesungsverzeichnisse der Westfälischen Wilhelms-Univesität Münster 1932-1939.

Neander J. 2006. The Danzig soap case: Facts and legends around "Professor Spanner" and the Danzig Anatomic Institute 19441945. German Stud Rev 29:63-86.

Neubert K. 1941. BA [Bundesarchiv] R3001 (alt R22), 1478, fol. 59 Neubert Rostock.

Neugebauer W. 1997. Wiener Psychiatrie und NS-Verbrechen. Referat im Rahmen der Arbeitstagung "Die Wiener Psychatrie im 20. Jahrhundert, Wien, Institut für Wissenschaft und Kunst, 20./ 21. Juni, 1997, URL: http://www.doew.at/frames.php?/thema/ thema_alt/justiz/euthjustiz/euth.html [Accessed March 2009].

Noack T. 2007. Begehrte Leichen. Der Berliner Anatom Hermann Stieve (1886-1952) und die medizinische Verwertung Hingerichteter im Natinoalsozialismus. Med Gesell Gesch 26:9-35.

Oehler-Klein S. (ed.) 2007. Die Medizinische Fakultät der Universität Giessen im Nationalsozialismus und in der Nachkriegszeit: Personen und Institutionen, Umbrüche und Kontinuitäten. Stuttgart: Franz Steiner Verlag. p 1-632.

Oleschinski B. 1992. Der "Anatom der Gynäkologen"- Hermann Stieve und seine Erkenntnisse über die Todesangst und weiblichen Zyklus. In: Kahrs H, Meyer A, Esch MG, editors. Modelle fur ein deutsches Europa- Ökonomie und Herrschaft im Grosswirtschaftsraum. Berlin: Rotbuch Verlag. p 211-218.

OMIM \#234200. Neurodegeneration with brain iron accumulation 1; NBIA1. URL: http://www.ncbi.nlm.nih.gov/entrez/dispomim.cgi? $i d=234200$ [Accessed June 2009].

Ortmann R. 1986. Die jüngere Geschichte des anatomischen Instituts der Universität Köln 1919-1984. Köln: Böhlau Verlag. p 1-136. 
Peiffer J. 1997. Hirnforschung im Zwielicht: Beispiele verfuehrbarer Wissenschaft aus der Zeit des Nationalsozialismus. Husum: Mathiessen Verlag. p 1-112.

Peiffer J. 2004. Hirnforschung in Deutschland 1849-1974. Berlin: Springer Verlag. p 1-1196.

Platen-Hallermund A. 1948. Die Tötung Geisteskranker. Heidelberg: Verlag der Frankfurter Hefte. p 1-131.

Proctor RN. 1994. Racial Hygiene: The Collaboration of Medicine and Nazism. In: Michalczyk JJ, editor. Medical Ethics and the Third Reich: Historical and Contemporary Issues. Kansas City: Sheed \& Ward, Kansas City. p 35-41.

Proctor RN. 2000. Nazi science and Nazi medical ethics: Some myths and misconceptions. Perspect Biol Med 43:335-346.

Prüll CR. 2003. Medizin am Toten oder am Lebenden? Pathologie in Berlin und in London, 1900-1945. Basel: Schwabe \& Co AG. p 367-401.

Redies C, Viebig M, Zimmermann S, Fröber R. 2005. Origin of corpses received by the anatomical institute at the University of Jena during the Nazi regime. Anat Rec B: New Anat 285:6-10.

Ritter H. 1992. Die Rolle der Anthropologie im NS-Staat. In: Peiffer J, editor. Menschenverachtung und Opportunismus. Zur Medizin im Dritten Reich. Tübingen: Attempto Verlag. p 172-178.

Roth K-H. 1984. Grosshungern und Gehorchen. Das Universitätsklinikum Eppendorf. In: Ebbinghaus A, Kaupen-Haas H, Roth K$\mathrm{H}$. Heilen und Vernichten im Mustergau Hamburg. Bevölkerungs- und Gesundheitspolitik im Dritten Reich. Hamburg: Konkret Literatur Verlag, pp 109-135.

Roth K-H. 1999. Schöner neuer Mensch. Der Paradigmenwechsel der klassischen Genetik und seine Auswirkungen auf die Bevölkerungsbiologie des "Dritten Reiches." In: Kaupen-Haas H, Saller $\mathrm{CH}$, editors. Wissenschaftlicher Rassismus. Analysen einer Kontinuitäet in den Huamn- und Naturwissenschaften. Frankfurt: Campus Verlag. p 346-424.

Rothmaler Ch. 1990. Gutachten und Dokumentation über das Anatomische Institut des Universitätskrankenhauses Eppendorf der Universität Hamburg 1933-1945. "1999," Zeitschr Sozialgesch des 20. u 21. JHD 2:78-95.

Schafft G. 2004. From Racism to Genocide: Anthropology in the Third Reich. Urbana and Chicago: University of Illinois Press. p 1-297.

Schmid A. 1965. Frankfurt im Feuersturm. Die Geschichte der Stadt im Zweiten Weltkrieg. Frankfurt am Main: Verlag Frankfurter Bücher. p 1-233.

Schmidt W. 1993. Leben an Grenzen. Autobiographischer Bericht eines Mediziners aus dunkler Zeit. Baden-Baden: Suhrkamp/ Nomos Verlagsgesellschaft. p 1-304.

Schmuhl H-W. 1987. Rassenhygiene, Nationalsozialismus, Euthanasie. Göttingen Vandenhoeck \& Rupprecht. p 1-526.

Schneider H. 1944. Zur Anatomie des Bewegungsapparates. Z Anat Entw 113:187-203.

Schönhagen B. 1992. Das Gräberfeld X auf dem Tübinger Stadtfriedhof Die verdrängte "Normalität" nationalsozialistischer Vernichtungspolitik. In: Peiffer J, editor. Menschenverachtung und Opportunismus. Tübingen: Zur Medizin im Dritten Reich. Attempto. p 69-92.

Schreiber H. 1942. Das Muskellager der menschlichen Gallenblasenwand im Vergleich zu der vierfüssiger Säuger. Z Anat Entw 111:91-150.

Schuhmacher G-H, Wischhusen H. 1970. Anatomia Rostochensis: Die Geschichte der Anatomie an der 550 Jahre alten Universität Rostock. Berlin: Akademieverlag. p 1-333.

Schwarze G. 1997. Kinder, die nicht zählten. Ostarbeiterinnen und ihre Kinder im zweiten Weltkrieg. Essen: Klartext. p 1-336.

Seidelman WE. 1996. Nuremberg lamentation: For the forgotten victims of medical science. BMJ 313:1463-1467.

Seidler E, Leven K-H. 2007. Die Medizinische Fakultät der AlbertsLudwigs-Universität Freiburg im Breisgau. Grundlagen und Entwicklungen. Freiburg: Verlag Karl Alber. p 1-885.

Spann G. 1999. Untersuchungen zur anatomischen Wissenschaft in Wien 1938-1945. Senatsprojekt der Universität Wien. Eine Zusammenfassung (Auszug aus: Dokumentationsarchiv des österreichischen Widerstandes. Jahrbuch 1999). URL: http:// www.doew.at/thema/thema_alt/ns_wissen/medizin/spann.html [Accessed March 2009].

Speck D. 2002. Zwangsarbeit an der universität und im Universitätsklinikum. Spurensuche, Fragen, Verstrickungen. In: Grün B,
Hofer H-G, Leven K-H, editors. Medizin und Nationalsozialismus. Die Freiburger Medizinische Fakultät und das Klinikum in der Weimarer Republik und im "Dritten Reich." Frankfurt am Main: Peter Lang Verlag. p 418-448.

Steege H. 1944. Über den histotopochemischen Nachweis von Vitamin $C$ in der menschlichen und tierischen Schilddrüse. Z Zellforsch 33:412-423.

Steegmann R. 2005. Struthof. Le KL-Natzweiler et ses Kommandos: Une Nébuleuse Concentrationnaire des Deux Côtés du Rhin 1941-1945. Strassbourg: Éditions de La Nuée Bleue. p 1-489.

Stöhr P. 1943. Studien zur normalen und pathologischen Histologie vegetativer Ganglien. I. Z Zellforsch 32:587-635.

Stuchlik G. 1984. Goethe im Braunhemd. Universität Frankfurt 1933-1945. Frankfurt A.M.: Röderberg-Verlag. p 1-232.

Taschwer K, Föger B. 2003. Konrad Lorenz. Eine Biographie. Wien: Paul Zsolnay Verlag. p 1-368.

Unger M. 1998. Ferdinand Wagenseil (1887-1967). Integrer Forscher und Bewahrer der Medizinischen Fakultät Giessen. Giessen: Wilhelm Schmitz Verlag. p 1-182.

Viebig M. 2002. Zu Problemen der Leichenversorgung des Anatomischen Institutes der Universität Halle vom 19. bis Mitte des 20. Jahrhunderts. In: Beiträge zur Geschichte der Martin-LutherUniversität 1502-2002. Halle: MDV, Mitteldeutscher Verlag Halle. p 117-146.

Vieten B. 1983. Medizinstudenten und Medizinische Fakultät in Münster im "Dritten Reich." In: Thien HG, Wienold H, editors. Münster-Spuren aus der Zeit des Faschismus. Zum 50. Jahrestag der nationalsozialistischen Machtergreifung. Münster: Edition Westfälisches Dampfboot. p 201-213.

von Ditfurth H. 1993. Innenansichten eines Artgenossen. Meine Bilanz, 3rd Ed. München: Deutscher Taschenbuch Verlag. p 1431.

von Hayek H. 1940a. Die läppchen und septa interlobaria der menschlichen Lunge. Z Anat Entw 110:405-411.

von Hayek H. 1940b. Über die Präkapillaren, die Arteriolen und dieTeilungsstellen der kleinen arterien in der menschlichen Lunge. Z Anat Entw 110:587-596.

von Möllendorf W. 1942. Beiträge zum Verständnis der Lungenkonstruktion. Z Anat Entw 111:224-245.

Voss H. 1940. Vergleichende Histotopochemische Untersuchungen über das Verhalten der Nebenniere zur Plasmalreaktion. Z Zellforsch 31:43-53.

Waltenbacher T. 2008. Zentrale Hinrichtungsstätten. Der Vollzug der Todesstrafe in Deutschland von 1937-1945. Scharfrichter im Dritten Reich. Berlin: Zwilling. p 1-263.

Weigmann K. 2001. In the name of science. The role of biologists in Nazi atrocities: Lessons for today's scientists. EMBO Rep 2:871875 .

Weindling P. 1989. Health, Race and German Politics Between National Unification and Nazism, 1870-1945. Cambridge: Cambridge University Press. p 1-641.

Weingart P. 1989. German eugenics between science and politics. Osiris 5:260-282.

Weingart P, Kroll J, Bayertz K. 1988. Rasse, Blut und Gene. Geschichte der Eugenik und Rassenhygiene in Deutschland. Frankfurt am Main: Suhrkamp. p 1-746.

Wendehorst A. 1993. Geschichte der Friedrich-Alexander-Universität Erlangen-Nürnberg 1743-1993. München: Verlag C.H. Beck. p $1-296$.

Winkelmann A, Schagen U. 2009. Hermann Stieve's clinical-anatomical research on executed women during the "Third Reich." Clin Anat 22:163-171.

Ziesche KT. 1943. Zur Histologie des Tuber cinereum des Menschen. Z Zellforsch 33:143-150.

Zimmermann V. 2007. Die medizinische Fakultät der Göttinger Georgia Augusta während der NS-Diktatur. In: Zimmermann V, editor. Leiden verwehrt vergessen. Zwangsarbeiter in Göttingen und ihre medizinische Versorgung in den Universitätskliniken. Göttingen: Wallstein Verlag. p 17-54.

Zitzelsperger S. 1944. Neue methoden zur untersuchung der reaktionskinetik histologischer färbungen. Z Anat Entw 113:164117. 